\section{Alkalinization of lidocaine $2 \%$ does not influence the quality of epidural anaesthesia for elective Caesarean section}

Giovanni Gaggero MD, Olivier Meyer MD,

Elisabeth Van Gessel MD, Kaplan Rifat MD
This double-blind randomized study compared the effects of an epidural injection of lidocaine hydrochloride $2 \%(\mathrm{HCl})$ (Group 1), alkalinized lidocaine $2 \%$ ( $1 \mathrm{ml} \mathrm{NaHCO}$ per $10 \mathrm{ml}$ of solution) injected either immediately (Group 2) or one hour after preparation (Group 3 ) in 45 parturients ( $n=15$ per group) scheduled for elective Caesarean section. Each patient received $16 \mathrm{ml}$ of one of the three solutions. The mean $\mathrm{pH}$ values measured just before administration with a pH-meter PHM $64 \mathrm{Met}-$ rohm $A G$ were 6.77 for the $\mathrm{HCl}$ lidocaine $2 \%$ solution, 7.34 for the freshly alkalinized solution and 7.35 for the solution prepared one hour before injection. The median maximal sensory level (range) observed was $T_{3}\left(T_{8}-C_{7}\right), T_{4}\left(T_{5}-C_{8}\right)$ and $T_{4}\left(T_{\sigma}-C_{6}\right)$, obtained after $19 \pm 6 \mathrm{~min}, 18 \pm 8 \mathrm{~min}$ and 16 \pm 6 min respectively for each group. A motor block of grade 2 or 3 on the Bromage scale was obtained in 11, 10 and 14 patients respectively. No failure was observed although 3, 5, and 2 patients in Groups 1, 2, and 3 respectively required a supplementary bolus $20 \mathrm{~min}$ after the initial injection because of inadequate sensory level or pain at the operative site. In conclusion, this study shows that neither fresh alkalinization of $2 \%$ lidocaine nor the delay of one hour between preparation and injection of the alkalinized solution influences the onset or quality of epidural anaesthesia for elective Caesarean section.

\section{Key words}

ANAESTHESIA: obstetrical, Caesarean section; ANAESTHETIC TECHNIQUES: epidural; ANAESTHETICS LOCAL: lidocaine, alkalinization.

From the Department of Anesthesiology, University Hospital of Geneva, 1211 Geneva 14, Switzerland.

Address corresondence to: Dr. G. Gaggero, Department of Anesthesiology, University Hospital of Geneva, 1211 Geneva 14, Switzerland.

Accepted for publication 16th July, 1995.
Cette étude randomisée, réalisée en double-aveugle, a comparé les effets anesthésiques de la lidocaüne $\mathrm{HCl} 2 \%$, de son alcalinisation immédiate à raison de 0,1 meq par $\mathrm{ml}$, et d'un délai d'une heure entre la préparation de la solution alcalinisée et son injection, en césarienne élective sous anesthésie péridurale continue chez 45 patientes. Chaque patiente a reçu une injection péridurale de $16 \mathrm{ml}$ de la solution correspondant au groupe auquel elle a été attribuée. Les $\mathrm{pH}$ moyens mesurés étaient 6.77 pour la lidocaïne $2 \%$ seule, 7.34 pour la solution fraichement alcalinisée et 735 pour la solution alcalinisée préparée à l'avance. La valeur médiane (étendue) du niveau sensitif maximal était à $D_{3}\left(D_{8}-C_{7}\right), D_{4}\left(D_{5}-C_{8}\right)$, et $D_{4}\left(D_{6} C_{6}\right)$, obtenu après $19 \pm 6$ minutes, $18 \pm 8 \mathrm{~min}$ et $16 \pm 6$ min pour les trois groupes respectivement. Un bloc moteur de degré 2 ou 3 selon l'échelle de Bromage a été obtenu chez 11,10 et 14 patientes respectivement. En conclusion, les résultats de cette étude indiquent d'une part que l'alcalinisation de la lidocä̈ne $2 \%$, et d'autre part qu'un délai d'une heure entre l'alcalinisation de la solution et son injection ninfluencent pas les caractéristiques d'une anesthésie péridurale pour césarienne.

Epidural anaesthesia is widely performed for Caesarean section. ${ }^{1,2}$ The literature describes several factors influencing onset, duration and quality of epidural anaesthesia in obstetrics ${ }^{3}$ among which the most important are: dose of local anaesthetics, volume and concentration of solutions, and additives.

In 1910, Läwen ${ }^{4}$ observed that the addition of sodium bicarbonate $0.5 \%$ to a $1 \%$ procaine solution enhanced local anaesthetic potency and reduced onset time. The proposed mechanism of action of sodium bicarbonate is an increase in the percentage of un-ionised molecules present in the local anaesthetic solution, thus facilitating their passage through biological membranes. 5,6 Clinical studies on alkalinization of local anaesthetic solutions have provided controversial results. Some authors ${ }^{6-11}$ report a faster onset and a better quality of sensory and 
motor blocks. Others ${ }^{12-16}$ have failed to show any clinical advantages of alkalinization over a plain solution.

When reviewing the studies, the timing of alkalinization of the local anaesthetic solution is not mentioned. Although Bonhomme ${ }^{17}$ has shown that an alkaline bupivacaine solution remains stable in solution for $24 \mathrm{hr}$, no data exist with an alkaline lidocaine solution. Our concern was to assess the stability of an alkalinized lidocaine solution using a clinical approach.

The aim of this study was to compare a plain solution of lidocaine $2 \%$ with two other identical solutions alkalinized one hour or immediately before epidural injection in patients undergoing elective Caesarean section.

\section{Methods}

After institutional approval, 45 consecutive unpremedicated female patients ASA status I or II undergoing elective Caesarean section were investigated.

In the operating room, the patients were monitored with an ECG, an automatic blood pressure cuff and a pulse-oximeter. A $17 \mathrm{G}$ venous catheter was inserted in a vein on the forearm and an isotonic crystalloid solution was infused at a rate of $10 \mathrm{ml} \cdot \mathrm{kg}^{-1}$ over $30 \mathrm{~min}$. Thereafter, fluid administration was tailored to haemodynamic variations and blood loss. All patients had a urinary catheter inserted.

The epidural space was punctured at the $\mathrm{L}_{3}-\mathrm{L}_{4}$ or $\mathrm{L}_{2}-\mathrm{L}_{3}$ interspace using an 18G Tuohy needle, with the patient in the left lateral position. The space was located using the loss of resistance technique. A 20G catheter was then threaded $4 \mathrm{~cm}$ cephalad. The patient was turned back to the supine position and a pillow placed under her right hip to minimize vena cava compression. A testdose of $2 \mathrm{ml}$ lidocaine $2 \%$ with epinephrine $1 / 200000$ was injected first. Five minutes later another $16 \mathrm{ml}$ of one of the following solutions were administered as rapidly as possible in a randomized double-blind fashion through the epidural catheter. The patients were attributed to their group by closed envelope the evening before, the solution was prepared by a nurse in an adjacent room.

Group 1: Lidocaine $2 \%$ with $1 \mathrm{ml}$ normal saline added for each $10 \mathrm{ml}$ of local anaesthetic.

Group 2: Lidocaine $2 \%$ with $1 \mathrm{mEq}(=1 \mathrm{ml})$ sodium bicarbonate $8.4 \%$ for each $10 \mathrm{ml}$ of local anaesthetic. The solution was prepared and injected immediately.

Group 3: Lidocaine $2 \%$ with $1 \mathrm{mEq}(=1 \mathrm{ml})$ sodium bicarbonate $8.4 \%$ for each $10 \mathrm{ml}$ of local anaesthetic. The solution was prepared one hour before injection.

If, $20 \mathrm{~min}$ after injection, the sensory level was below $\mathrm{T}_{6}$ and/or motor block was less than grade 2 on the
TABLE I Patient characteristics and preanaesthetic haemodynamic values (mean $\pm \mathrm{SD}$ )

\begin{tabular}{lccc}
\hline & $\begin{array}{c}\text { Group I } \\
(n=15)\end{array}$ & $\begin{array}{c}\text { Group 2 } \\
(n=15)\end{array}$ & $\begin{array}{c}\text { Group 3 } \\
(n=15)\end{array}$ \\
\hline Age (yr) & $33 \pm 4$ & $31 \pm 6$ & $31 \pm 5$ \\
Weight (kg) & $73 \pm 16$ & $72 \pm 11$ & $74 \pm 7$ \\
Height (cm) & $158 \pm 9$ & $161 \pm 7$ & $164 \pm 7$ \\
Pregnancy (wk) & $38 \pm 1$ & $39 \pm 1$ & $38 \pm 1$ \\
ASA status I/II/III & $15 / 0 / 0$ & $15 / 0 / 0$ & $15 / 0 / 0$ \\
MAP (mmHg) & $87 \pm 16$ & $92 \pm 9$ & $91 \pm 4$ \\
HR (beats $\cdot$ min $\left.^{-1}\right)$ & $84 \pm 5$ & $85 \pm 13$ & $90 \pm 17$ \\
\hline
\end{tabular}

MAP $=$ mean arterial pressure, $\mathrm{HR}=$ heart rate, Group $1=$ plain lidocaine $2 \%$, Group 2 = freshly alkalinized lidocaine $2 \%$, Group $3=$ alkalinized lidocaine $2 \%$ prepared one hour before.

Bromage scale $(0=$ no motor block, $1=$ patient unable to raise extended leg, 2 = patient unable to flex the knee, 3 = patient unable to move the ankle) a supplementary $4 \mathrm{ml}$ bolus of the same solution was injected. If, ten minutes after this supplementary bolus, the sensory level was still below $\mathrm{T}_{6}$, the case was considered a failure and general anaesthesia was performed. Surgery started as soon as a sensory level of $T_{6}$ was reached.

The following variables were noted every two minutes during the first $20 \mathrm{~min}$ after injection and then every five minutes up to $30 \mathrm{~min}$ after initial injection:

- Upper sensory level using the pin-prick test in the midaxillary line, bilaterally, with a 24-gauge needle.

- Maximal degree of motor block on the Bromage scale.

- Variations in the mean arterial pressure (MAP) and heart rate (HR) until the end of surgery. If MAP decreased by $>30 \%$ of the baseline value, 5 to $10 \mathrm{mg}$ ephedrine, were administered $i v$. If the HR slowed to $<45 \mathrm{bpm}, 0.5 \mathrm{mg}$ atropine was injected $i v$.

- Volume of fluids infused and urinary flow were noted every $30 \mathrm{~min}$ until the end of surgery.

The $\mathrm{pH}$ of each solution was determined just before administration with a pH-meter PHM 64, Metrohm $\mathrm{AG}^{\circledR}$.

The data are expressed as mean \pm SD or median (range). Groups were analysed using analysis of variance (ANOVA), the Kruskall-Wallis test or the Mann Witney $\mathrm{U}$ test as required. A $P<0.05$ was considered significant.

\section{Results}

Patient characteristics are presented in Table I. No differences were noted among groups.

The mean $\mathrm{pH}$ of each solution was $6.77 \pm 0.1$ in Group $1,7.34 \pm 0.03$ in Group 2 and $7.35 \pm 0.03$ in Group 3 (NS).

The evolution of the sensory block during the $20 \mathrm{~min}$ after the initial epidural injection of local anaesthetic is 


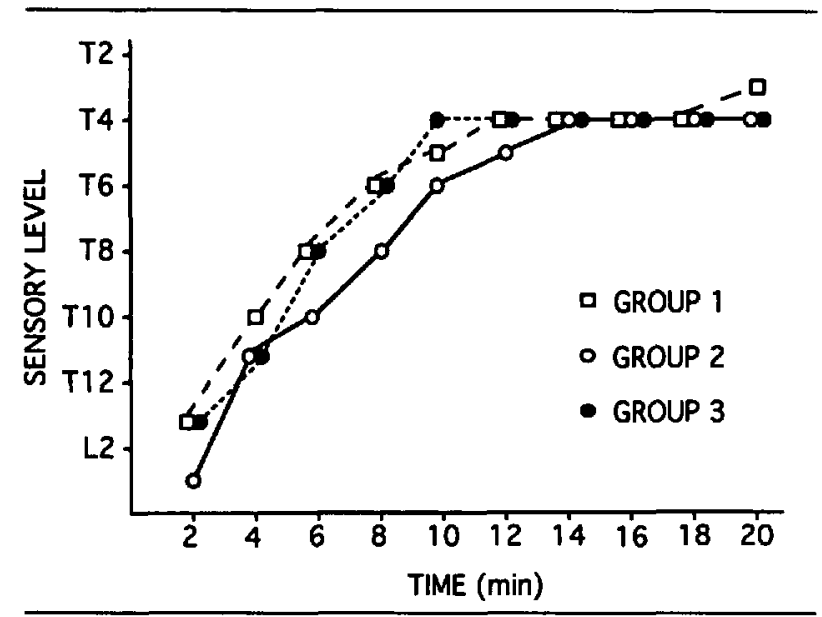

FIGURE 1 Sensory levels obtained during the first $20 \mathrm{~min}$ after epidural injection for the three groups, expressed as median ( $n=15$ for each group). Group $1=$ plain lidocaine $2 \%$, Group $2=$ freshly alkalinized lidocaine $2 \%$, Group $3=$ alkalinized lidocaine $2 \%$ prepared one hour before.

TABLE II Anaesthetic characteristics during the first $30 \mathrm{~min}$ after epidural injection of lidocaine $2 \%$ for the three groups. Results are expressed as mean $\pm \mathrm{SD}$ or median (range)

\begin{tabular}{llll}
\hline & $\begin{array}{l}\text { Group I } \\
(n=15)\end{array}$ & $\begin{array}{l}\text { Group 2 } \\
(n=15)\end{array}$ & $\begin{array}{l}\text { Group 3 } \\
(n=15)\end{array}$ \\
\hline $\begin{array}{llll}\text { Maximal sensory level } \\
\text { Obtained after (min) }\end{array}$ & $\begin{array}{l}\mathrm{T}_{3}\left(\mathrm{~T}_{8}-\mathrm{C}_{7}\right) \\
19 \pm 6\end{array}$ & $\begin{array}{l}\mathrm{T}_{4}\left(\mathrm{~T}_{5} \mathrm{C}_{8}\right) \\
18 \pm 8\end{array}$ & $\begin{array}{l}\mathrm{T}_{4}\left(\mathrm{~T}_{6} \mathrm{C}_{6}\right) \\
16 \pm 6\end{array}$ \\
$\begin{array}{llll}\text { Number of patients with a } \\
\text { motor block grade 2 or 3 }\end{array}$ & 11 & 10 & 14 \\
Obtained after (min) & $11 \pm 13$ & $7 \pm 3$ & $13 \pm 7$ \\
\hline
\end{tabular}

Group 1 = plain lidocaine $2 \%$, Group 2 = freshly alkalinized lidocaine $2 \%$, Group $3=$ alkalinized lidocaine $2 \%$ prepared one hour before.

shown in Figure 1. No differences were observed among groups. The median values of maximal sensory levels observed and mean onset times were comparable (Table II).

Inadequate sensory levels occurred in two patients in Group 1, three in Group 2 and one in Group 3. Furthermore, although maximal sensory levels of $T_{4}$ and $T_{5}$ were reached, one patient in Group 1, two in Group 2 and one in Group 3 required a supplementary bolus $20 \mathrm{~min}$ after the initial injection because of pain at the operative site. No failure was noted.

The number of patients presenting with motor block of grade 2 or 3 on the Bromage scale as well as the mean onset time of motor block were not different among groups (Table II).

Maximal variations in MAP are shown in Figure 2. The number of patients requiring ephedrine and the mean dose (mg) of ephedrine administered are shown in Table III. No differences were observed among groups. One

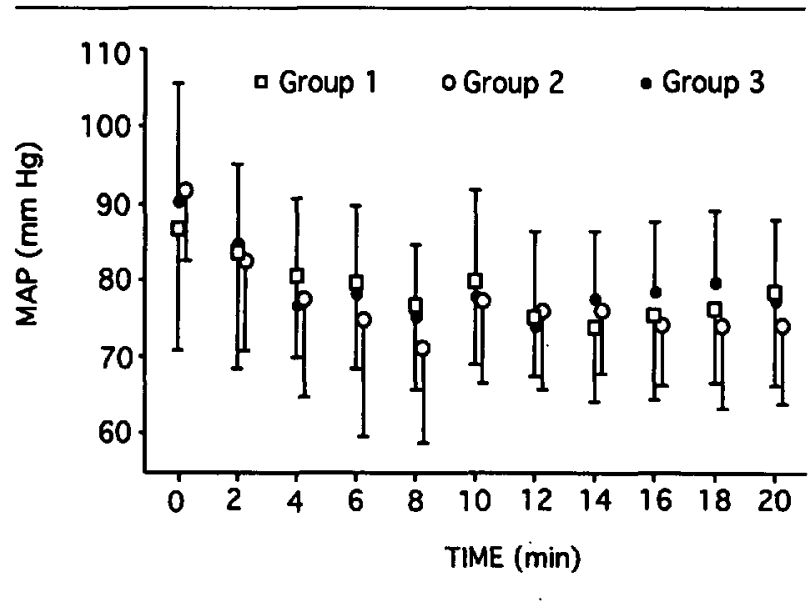

FIGURE 2 Evolution of mean arterial pressure (MAP) during the first $20 \mathrm{~min}$ after epidural injection for the three groups (mean $\pm \mathrm{SD}$, $n=15$ for each group). Group 1 = plain lidocaine $2 \%$, Group $2=$ freshly alkalinized lidocaine $2 \%$, Group $3=$ alkalinized lidocaine $2 \%$ prepared one hour before.

TABLE III Maximal haemodynamic changes noted during the first 30 min after epidural injection for the three groups (mean $\pm S D$ )

\begin{tabular}{lccc}
\hline & $\begin{array}{c}\text { Group I } \\
(n=15)\end{array}$ & $\begin{array}{c}\text { Group 2 } \\
(n=15)\end{array}$ & $\begin{array}{l}\text { Group 3 } \\
(n=15)\end{array}$ \\
\hline $\begin{array}{l}\text { Maximal haemodynamic } \\
\text { changes from baseline values } \\
\text { for. }\end{array}$ & & & \\
- MAP (\%) & $-29 \pm 12$ & $-35 \pm 13$ & $-28 \pm 15$ \\
- HR (\%) & $-10 \pm 32$ & $+6 \pm 28$ & $-12 \pm 30$ \\
$\begin{array}{l}\text { Onset time } \\
\text { - MAP (min) }\end{array}$ & $14 \pm 8$ & $13 \pm 8$ & $13 \pm 8$ \\
- HR (min) & $12 \pm 10$ & $18 \pm 10$ & $13 \pm 7$ \\
$\begin{array}{l}\text { Number of patients requiring } \\
\quad \text { ephedrine }\end{array}$ & 6 & 9 & 8 \\
Mean dose of ephedrine (mg) & $12 \pm 7$ & $11 \pm 9$ & $12 \pm 5$ \\
\hline
\end{tabular}

MAP $=$ mean arterial pressure, $H R=$ heart rate, Group $1=$ plain lidocaine $2 \%$, Group $2=$ freshly alkalinized lidocaine $2 \%$, Group $3=$ alkalinized lidocaine $2 \%$ prepared one hour before.

patient in Group 1 and two patients in Group 3 needed iv atropine for bradycardia $<45 \mathrm{bpm}$.

The duration of surgery was $49 \pm 13 \mathrm{~min}$ in Group $1,51 \pm 8 \mathrm{~min}$ in Group 2 and $53 \pm 18 \mathrm{~min}$ in Group 3 (NS). The total volumes of crystalloid infused were $1140 \pm 297 \mathrm{ml}, 1123 \pm 228 \mathrm{ml}$ and $1206 \pm 273 \mathrm{ml}$ respectively for the three groups (NS). Total urine volume was $107 \pm 106 \mathrm{ml}, 82 \pm 41 \mathrm{ml}, 61 \pm 58 \mathrm{ml}$ respectively for the three groups (NS). Length of hospital stay was $6.7 \pm 1.5,7.2 \pm 1.4$ and $6.3 \pm 0.8$ days respectively for each group (NS). No patient presented any complication. 


\section{Discussion}

Local anaesthetics are weak bases with a pKa ranging from 7.7 to 8.9 for the commonly used drugs. Most commercial preparations are acidic to improve the stability of the solution but, at low $\mathrm{pH}$, less drug is available in the undissolved active form. The relative proportion of undissociated to dissociated form is dependent on the Henderson-Hasselbach equation. Alkalinization improves the amount of local anaesthetic in the undissociated lipid soluble form, theoretically allowing a better passage through the nerve membrane, thus improving the quality and speed of surgical anaesthesia.

We found no clinical improvement of quality of anaesthesia for either alkalinized solution compared to lidocaine $\mathrm{HCl}$. Several explanations can be advanced. First the lack of effect could be due to the weak pH modifications observed with alkalinization of non-epinephrine containing solutions. In a recent in vitro study, Berrada ${ }^{15}$ observed that alkalinization of non-epinephrine containing local anaesthetics, whose $\mathrm{pH}$ values are already $>6$, was not useful, i.e., the increase in concentration of the ionized fraction was limited (from two to four times). However, in the same study, with alkalinization of epinephrine containing solutions of lidocaine or bupivacaine that are more acidic, the concentration of the un-ionised active fraction increased from 1000 to 3000 times.

Clinically, the results of different studies are controversial. Di Fazio et al. ${ }^{7}$ noted that the onset time of sensory block was inversely proportional to the $\mathrm{pH}$ of a solution of lidocaine $1.5 \%$ with epinephrine injected epidurally. Other authors, while finding a quicker onset time ${ }^{9}$ and a better quality of epidural anaesthesia using alkalinized solutions, have failed to show better results in groups where alkalinization was performed using an epinephrine-containing solution compared with nonepinephrine-containing solutions.

Using a 1:400,000 epinephrine-containing lidocaine $2 \%$ solution, Liepert et al., ${ }^{12}$ who studied patients undergoing Caesarean section, did not observe any difference in onset, spread and quality of sensory block. In his study, epinephrine was not present in the commercial acidic solution and was added after alkalinization, thus resulting probably in less pH modification. In our study, very similar to that of Liepert but using a non-epinephrinecontaining lidocaine solution, $\mathrm{pH}$ modifications were similar to those of Liepert and no improvement in onset or quality of anaesthesia was observed.

Second, as previously noted, the methodology of the different studies cited ${ }^{6-16}$ did not state the delay between alkalinization of local anaesthetic and its epidural injection. One explanation for the differences in the results observed in the literature is that alkalinization is always performed at the bedside with little uniformity in timing between the preparation and the epidural injection of the local anaesthetic solution. Lidocaine could then become unstable at neutral or alkaline $\mathrm{pH}$ values, thus being less effective if alkalinized too early.

Our study did not show any difference between the immediate preparation and the one-hour delayed preparation of alkalinized lidocaine. Thus, lack of lidocaine stability at neutral or alkaline $\mathrm{pH}$ cannot be retained as an explanation for the differences observed in the literature.

Finally, another reason explaining the absence of a difference between the alkalinized and the plain solutions of lidocaine is the large dose of local anaesthetic used in our study which is sufficient to speed the perineural diffusion of the local anaesthetic, ${ }^{18}$ thus overwhelming the effect of alkalinization.

In conclusion, this study shows that neither immediate alkalinization of a lidocaine $2 \%$ solution, nor alkalinization of lidocaine $2 \%$ one hour before its epidural injection influence the spread or quality of anaesthesia for Caesarean section.

\section{References}

1 Lussas $S A$, Datta $S$. Anesthesia for cesarean delivery. Part I: General considerations and spinal anesthesia. International Journal of Obstetric Anesthesia 1992; 1: 79-91.

2 Lussos SA, Datta S. Anesthesia for cesarean delivery. Part II: Epidural anesthesia, intrathecal and epidural opioids, venous air embolism. International Journal of Obstetric Anesthesia 1992; 1: 208-21.

3 Park WY. Factors influencing distribution of local anesthetics in the epidural space. Reg Anesth 1988; 13: 49-57.

4 Läwen $A$. Ueber die Verwendung des Novocains in Natriumbikarbonat - Kochsalzlossungen zur lokalen Anästhesie. Muenchener Medizinische Wochenschrift 1910; 57: 2044-6.

5 Condouris GA, Goebel RH, Brady T. Computer simulation of local anesthetic effects using a mathematical model of myelinated nerve. J Pharmacol Exp Ther 1976; 196: 737-45.

6 Wong $K$, Strichartz GR, Raymond SA. On the mechanism of potentiation of local anesthetics by bicarbonate buffer: drug structure-activity studies on isolated peripheral nerve. Anesth Analg 1993; 76: 131-43.

7 DiFazio CA, Carron H, Grosslight KR, Mascicki JC, Bolding WR, Johns RA. Comparison of $\mathrm{pH}$-adjusted lidocaine solutions for epidural anesthesia. Anesth Analg 1986; 65: 760-4.

8 McMorland GH, Douglas MJ, Jeffery WK, et al. Effects of $\mathrm{pH}$-adjustment of bupivacaine on onset and duration of epidural analgesia in parturients. Can Anaesth Soc J 1986; 33: 537-41.

9 McMorland GH, Douglas MJ, Axelson JE, et al. The effects of $\mathrm{pH}$-adjustment of bupivacaine on onset and dura- 
tion of epidural anaesthesia for Caesarean section. Can J Anaesth 1988; 35: 457-61.

10 Hilgier $M$. Alkalinisation of bupivacaine for brachial plexus block. Reg Anesth 1985; 10: 59-61.

11 Batra MS. Adjuvants in epidural and spinal anesthesia. Anesthesiology Clinics of North America 1992; 10: 14-6.

12 Liepert DJ, Douglas MJ, McMorland GH, Gambling DR Kim JHK, Rass PLE. Comparison of lidocaine $\mathrm{CO}_{2}$, two percent lidocaine hydrochloride and $\mathrm{pH}$ adjusted lidocaine hydrochloride for Caesarean section anaesthesia. Can $\mathbf{J}$ Anaesth 1990; 37 3: 333-6.

13 Verborgh $C$, Claeys $M-A$, Camu $F$. Onset of epidural blockade after plain or alkalinized $0.5 \%$ bupivacaine. Anesth Analg 1991; 73: 401-4.

14 Jacquinot $P$, Jorrot JC, Dailland P, Lirzin JD, Conseiller C. Alcalinisation de la bupivacaine dans l'association fentanyl-bupivacaïne pour l'analgésie péridurale obstétricale. Ann Fr Anesth Reanim 1990; 9: 16-9.

15 Berrada R, Chassard D, Bryssine S, Berthier S, Bryssine B, Boulétreau $P$. Effects in vitro de l'alcalinisation de la bupivacaine $0,25 \%$ et de la lidocaine $2 \%$. Ann Fr Anesth Reanim 1994; 13: 165-8.

16 Bedder MD, Kozody R, Craig DB. Comparison of bupivacaine and alkalinized bupivacaine in brachial plexus anesthesia. Anesth Analg 1988; 67: 48-52.

17 Bonhomme L, Benhamou D, Jebri $M$, et al. Chemical stability of bupivacaine in $\mathrm{pH}$-adjusted solutions. Anesthesiology 1988; 69: 754-6.

18 Cousins MJ. Epidural neural blockade. In: Cousins MJ, Bridenbaugh PO (Eds.). Neural Blockade in Clinical Anesthesia and Management of Pain. Philadelphia: J.B. Lippincott, 1980; 176-274. 